VARIA 


\title{
A origem do desejo n' O Santo da Montanha de Camilo Castelo Branco
}

\author{
Sérgio Guimarães de Sousa \\ ILCH - Universidade do Minho
}

Mulheres do feitio de Mécia, quando não amam o rouxinol das balças, amam rapazes magros, macilentos e cismadores. Éo mais usual.

Camilo Castelo Branco, O Santo da Montanha

Em 1866, Camilo publica $O$ Santo da Montanha. A narrativa
não foge aos esquemas semânticos típicos do escritor. Temos
- amores contrariados, um trajecto amoral e associal, a Providência a punir os desvarios comportamentais e, a rematar a acção, expiações reparadoras e castigos providenciais. O herói, que vira anti-herói (satanizase), perde-se de amores por uma moça leviana, imatura, coquete e interesseira. A atraç̧ão maléfica é enormemente tributária, como já procurei demonstrar noutros sítios, de uma rivalidade mimética, tal como é teorizada por René Girard. ${ }^{1}$ De facto, exacerbado por um ciúme insuportável, Baltasar enreda-se numa espiral de violência cujo âmago se explica por um comportamento de pura rivalidade mimética em torno de um objecto desejado (Mécia) absurdamente inflacionado. Não voltarei, portanto, a esta questão. Interessa-me agora reflectir sobre o que sucedeu antes da espiral de violência, ou seja, perscrutar a origem do desejo de Baltasar, circunscrever o que fez com que o morgado desejasse cegamente Mécia, sobretudo numa altura em que é já inegável a distância que separa a filha de Lopo Sampaio

${ }^{1}$ SOUSA, 2005, p. 191-262; e vide SOUSA, p. 101-11, nov. 2005. 
do ideal de uma mulher-anjo. Recorde-se, aliás, além de D. José, o manifesto desinteresse por Mécia do até então rival Salvador Teixeira, que «Para confirmação da nenhuma importância em que tinha a menina de Ansiães, trazia [...] novos rebentos de coração negociados com três ou cinco meninas de Braga $; ;$, ou o que vem na carta que lhe dirige seu primo Melchior, a qual, para desespero de Baltasar, dá conta dos preparativos que deixam antever o casamento de Mécia com D. José. No primeiro parágrafo da missiva, inegavelmente folgado de escárnio, escreve Melchior que «Mécia é a primeira douda destes reinos, e suas conquistas e navegaçōes de Etiópia, Arábia e Pérsia!ı. ${ }^{3}$ Como se isto não bastasse, para além dos conselhos de Frei António de Cristo, espécie de duplo do protagonista que cumpre as funçōes, digamos, de Superego freudiano de Baltasar (dos ímpetos que irrompem no fidalgo e que este tem forçosamente de recalcar em nome de algo mais fundo, segundo o frade), o fidalgo de Ansiães também ouve a voz da opinião pública naquele comentário, atrás citado, e apreciável no teor de insinuação que comporta, do reitor de Selores («Seu tanto ou quanto namoradeira...»). O reitor do Colégio de São Bartolomeu no Funchal, o padre Inácio de Paiva, diria, com o mesmo sentido, que Mécia era uma «ventoinha de torre». ${ }^{4} \mathrm{E}$ observe-se aqui que Baltasar, longe de fechar os ouvidos às palavras do reitor de Selores, muito mais comedidas a partir do instante em que se apercebe que interage com "a pessoa que a morgadinha ama», 5 agradece-lhe o «obséquio impagável»; ${ }^{6}$ e, com a lucidez necessária para reconhecer uma desproporção sentimental na sua relação com Mécia, admite reservas ao afecto que lhe vota, questionando o merecimento da destinatária. ${ }^{7}$

\footnotetext{
${ }^{2}$ CASTELO BRANCO, 1972, p. 186.

${ }^{3}$ CASTELO BRANCO, 1972, p. 187.

${ }^{4}$ CASTELO BRANCO, 1972, p. 232-3.

5 CASTELO BRANCO, 1972, p. 119.

${ }^{6}$ CASTELO BRANCO, 1972, p. 119.

${ }^{7}$ Cf. CASTELO BRANCO, 1972, p. 119-20.
} 
2. É certo que o desejo que brota no íntimo de Baltasar provém de uma panóplia de mentiras a que dificilmente a personagem, propensa que é para o sentimentalismo romântico, se furta. As simulaçōes que Mécia leva a efeito, propositadas no sentido de transmitirem uma imagem de si (angelical) capaz de seduzir o morgado, surtem efeito. Baltasar, ao invés de D. José, torna-se numa presa fácil da narcotização amorosa.

Porém, é incontornável que se coloque esta questão essencial: como entender que, a despeito dos avisados conselhos do primo, nos silêncios, nas falas e nos actos da rapariga, o fidalgo de Olarias ilusoriamente encontre as feiçôes de uma inocente menina e vislumbre, num transbordo crescente de felicidade, uma afinidade electiva? Ou ainda: qual a razão pela qual as admoestações de D. José não bastaram para alertar o primo dos perigos da insana paixão, desviando-o do caminho de Mécia? Ou então: como é que as incongruências da rapariga não saltaram à vista do moço apaixonado? $\mathrm{E}$ não é, claro está, suficiente responder que a falácia de Baltasar interpretar inocência e afinidade amorosa na morgada radica no testemunho abonatório do pai condescendente, o senhor de Ansiães, que, não poupando mimos nem elogios à filha, acabaria por creditar a leitura do morgado de Olarias.

Comecemos por dizer, e justamente a propósito de Lopo Sampaio, que o pai de Mécia vê com espanto - como uma desordem que o Antigo Regime, muito ao inverso da modernidade romântica, tem dificuldade em entender - o facto de Baltasar ter trocado o governo de sua casa por uma fantasia: a de viver sozinho nas serras, apenas com uma matilha de cães, nutrindo-se do produto da sua caça. Ou seja, apossado por um ímpeto de liberdade, às avessas do que se esperava do seu estatuto de morgado, resolveu comutar, conforme confessa sem complexos, o fastio dos livros e largar a casa familiar, desfazendo-se da incumbência que lhe cabia de a governar, em prol de uma existência itinerante de caçador solitário. ${ }^{8}$ Entregou-se a um modo de vida discrepante com o rumo usual reservado aos primogénitos aristocratas, passando a viver à margem da sociedade e das regalias atinentes

${ }^{7}$ CASTELO BRANCO, 1972, p. 22-23. 
ao seu estatuto social. Confinou-se a um isolamento invulgar nas sociedades tradicionais (a um isolamento de cariz romântico-moderno), já que no Antigo Regime, como refere o sociólogo Niklas Luhmann, «era rara la acción solitária, pues la casa y la vida, en general, ofrecían pocas posibilidades para el aislamiento». ${ }^{9}$ Digamos que se tornou, para usar aqui uma classificação proposta por Louis Dumont, num «individu-hors-du-monde», quer dizer, num indivíduo independente e autónomo. ${ }^{10}$ Numa palavra, Baltasar não se submeteu à ordem patriarcal.

A personagem dá, portanto, provas de um individualismo moderno, rompendo socialmente com a representação tradicional (que é marcada por uma ordem fechada e hierarquizada). Efectivamente, o herói define-se não mediante uma retrospecção capaz de lhe pôr em relevo as origens genealógicas, mas, antes, em termos de uma autonomia, que é uma autonomia moderna ainda que fantasiada na imagem de um viver solitário no meio das serras. Baltasar como que rasurou a sua pertença sócio-familiar e, com isso, um dos vínculos fundamentais do Antigo Regime, sem o qual o indivíduo corria o sério risco de marginalidade (é por isso compreensível o espanto do patriarca Lopo diante do relato de Baltasar). Observe-se que o protagonista contrariou a ordem patriarcal por duas vezes: primeiro, quando estudou ao arrepio da vontade paterna; e, segundo, ao renunciar ao dever filial de assumir o governo da casa familiar por morte do pai. Se nos quisermos inspirar em Jacques Lacan, que, a propósito de James Joyce, fala no Nome do pai, ${ }^{11}$ expressão que em francês (le Nom du père) homofonicamente pode ser lida, conforme sabemos, como o Não do pai (le Non du père), podemos aqui falar num Não do filho, isso no sentido de salientar a negação dupla do filho em relação ao pai (castração imposta pelo filho). Em primeiro lugar, porque o filho desobedece a um interdito do pai, quer dizer, nega o não do pai (le Non du père): começa os estudos, como se disse, a despeito

${ }^{9}$ LUHMANN, 1998, p. 381.

${ }^{10}$ DUMONT, 1983.

${ }^{11}$ LACAN, 1986, p. 28. 
da vontade do progenitor. Não acatou a vontade do pai, não lhe respeitou o não, impôs a esse não do pai, a esse interdito paterno, um não seu (o Não do filho). Em segundo lugar, porque renunciou aos deveres filiais do patriarcado. Sendo filho primogénito, cumpria-lhe tomar o governo da casa familiar. Ora Baltasar entrega-a ao irmão secundogénito e prefere refugiar-se nas serras. Nega assim uma convenção basilar da ordem patriarcal, a que manda o filho mais velho encabeçar o domínio familiar, falecido o pai. E o pai do protagonista - note-se - não pôde inverter esta segunda negação do filho, este segundo não do filho, uma vez que Baltasar não chegou a tempo de o assistir moribundo, o que também se poderia ler como uma negação suplementar do filho. ${ }^{12}$

Ora bem, além da rasura do patriarcado (a revolta contra o pai), o exílio serrano alarga-se a uma outra leitura mais vasta. Significa uma notória rejeição da própria realidade social no seu todo. $\mathrm{O}$ protagonista podia muito bem renunciar ao seu vínculo familiar, sem, contudo, partir para as montanhas. Iria para outra região, para outro país, para outro lugar onde continuasse a beneficiar de práticas sociais e de convívio. Ao refugiar-se na solidão das serras, Baltasar procurou cortar com o mundo social. Quis tornar-se num indivíduo emancipado do social (da hierarquia e do degree) ou, por outras palavras, num indivíduo socialmente deslocado (marginal no tocante à esfera social). A ruptura denuncia-lhe um desajuste à realidade do mundo social e conecta-se com o que, a certa altura de uma troca de argumentos com Mécia, lhe diz: "que o mundo é um covil de feras». ${ }^{13}$ Este entendimento muito disfórico da realidade social, que se coaduna com o

${ }^{12}$ A propósito, refira-se que ao negar a administração da casa familiar, Baltasar não só nega o pai, ou se quisermos, o Não do pai, como também de certa maneira lhe nega o nome (o Nome do pai). Com efeito, a recusa em tomar conta da propriedade familiar, por inerência, faz com que quem passe a perpetuar o nome do pai, na relação que esse nome mantém com a linhagem e a propriedade familiar, seja o filho segundo e não Baltasar.

${ }^{13}$ CASTELO BRANCO, 1972, p. 87. 
egotismo que tipifica o protagonista romântico, ${ }^{14}$ deixa a suposição clara de uma repulsa pelo mundo (o mundo como algo de abjecto ou repulsivo), ou melhor, da realidade do mundo enquanto espaço social. Daí a solução da fuga para um mundo outro, o mundo extra-social das montanhas.

Mas, para o que agora nos interessa - perceber as razões do logro sentimental de Baltasar por Mécia -, convém assinalar dois aspectos. Primeiro aspecto: observar que a vivência nas montanhas pressupóe como que o estatuto de um estágio educativo (e conforma-se a um conjunto de tópicos muito presentes na literatura, desde os seus primórdios: a natureza como mestra que educa, o livro da natureza...). E, a esse nível, funciona como uma aprendizagem (sem livros) que o liberta dos conteúdos civilizacionais que, em sociedade, empecilham a formação de um carácter mais humano e menos socialmente regulado. Aliás, ao deixar o contexto social, Baltasar renunciou, para usar uma terminologia luhmanniana, ao meio de comunicação generalizado simbolicamente do dinheiro. E o interlúdio das serras, onde esse meio de comunicação generalizado simbolicamente se afigura dispensável, afora outros (como, por exemplo, o poder) e além de todos os códigos sociais que apenas fazem sentido em regime social, livra-o do preconceito, das mentiras sociais, dos ludíbrios civilizacionais. Deste modo, Baltasar regressa das serras como se viesse educado de outro modo, de um modo, por assim dizer, mais correcto (despretensioso, desprovido de preconceitos e de outros lugares-comuns que a sociedade falaciosamente incute), sem perversóes sociais, o que,

${ }^{14}$ Egotismo presente na presunção do herói romântico de gozar de uma superioridade (moral, sentimental, heróica...) sobre os outros. Neste caso concreto, na conversa a que nos referimos, Baltasar ostenta a presunção de uma superioridade sentimental sobre os homens a que se refere a moça e, em consequência disso, lança-lhe uma súplica no sentido de esquecer esses outros e de somente se fixar nele (egotismo): «não me iguale aos homens que neste instante lhe acodem à memória... Eu queria que não recordasse ninguém neste momento... ninguém!...» (CASTELO BRANCO, 1972, p. 87). 
pensando em Rousseau, o assemelha um tanto a um 'bom selvagem', ${ }^{15}$ como se nota na conversa que mantém com Lopo de Sampaio, na qual rebate os preconceitos sociodoutrinários do anciāo. Porém, convém registar uma ressalva. Baltasar, partindo para as serras, não regressou a um genuíno estado selvagem. A linguagem e os modos que o fidalgo emprega são os que supomos em gente de corte ou afim do convívio social e não aqueles que suspeitaríamos num caçador serrano. A razão da desconformidade afigurase óbvia: a personagem viveu a infância e parte da mocidade em conformidade com a sua condição social, sendo que a fuga recente para as serras lhe não anulou o trato e as formalidades, próprios de um fidalgo, que lhe foram inculcados desde que terá nascido.

Pois bem, muito curiosamente, ou nem tanto, este interlúdio educativo das serras, que lhe permitiu desaprender preconceitos e ludíbrios, tornou-o indefeso perante esses ludíbrios e esses preconceitos. Regista-se assim uma contradição notória: ao fim e ao cabo, o que o estágio nas serras lhe garante é uma preparação para ser vítima daquilo contra o qual a natureza o educava, digamos, por omissão. Por isso que sucumbe a Mécia, ao contrário de D. José, que provém de Lisboa, ou seja, dos meandros da sociedade, e que daí vem bem preparado para lidar com os ludíbrios da sociedade. Quanto a Baltasar, a sua passagem pela natureza, que tece uma inegável ponte com o final da narrativa (o protagonista acabará na condição, novamente, de eremita, porém com uma diferença central: o regresso à solidão da montanha servirá, como é típico nos enredos camilianos, para expiar os crimes e estará ao serviço de um processo de santificação), como que lhe tolheu a capacidade de discernimento, tornou-o indefeso perante as mentiras sociais e mormente perante a falaciosa imagem ostentada por Mécia, o que não sucede com o primo nem com o fidalgo de Guimarães (quando D. José, negando tudo o que dissera a Baltasar acerca da moça, se deixará seduzir, a paixão do morgado de Alijó enquadra-se mais numa questão de rivalidade e não terá a ver propriamente com ludíbrio social).

${ }_{15}$ Abordei alguns aspectos das relações entre o Baltasar das serras e a figura do 'bom selvagem' de Rousseau em SOUSA, 2008, p. 135-152. 
Segundo aspecto: indissociável da sua incapacidade de notar a mentira social, sublinhe-se, ou não fosse o protagonista um herói romântico, que Baltasar padece de um flagrante idealismo, patente justamente na sua radical decisão de tudo abandonar e de passar a viver na condição (precária) de caçador. A fantasia de rumar às serras e de lá (sobre)viver, entregando-se ao extremo de uma vida solitária, tendo por alimentos o produto da caça e como dormida choupanas, a resolução de se afastar de tudo e de todos (exceptuando os pastores que vai encontrando), sem cuidar das suas responsabilidades sócio-familiares, essa fantasia pressupõe uma forte dose de idealismo.

Ora é precisamente esse idealismo, traço característico do herói romântico, que incita Baltasar a uma idealização de Mécia que se traduz na propulsão da moça para a condição de um simulacro divino, para o estatuto de uma mulher-anjo; idealismo que o leva, debruçado sobre o Tâmega, a sonhar imagens transcendentes de Mécia, a divinizá-la. E não adianta que o primo $\mathrm{D}$. José, por mais de uma vez, o tente chamar à razão. De nada valem os seus pertinentes avisos. São letra morta ou vazia face à visão idealizada que o protagonista, nestes capítulos iniciais (os oito primeiros), alimenta da morgada de Ansiães. Ou, para dizer com a terminologia que propôs Stendhal em De L'Amour, Baltasar sofre um processo de "cristalização»" (André Breton falaria em amor louco).${ }^{17} \mathrm{E}$, de resto, a situação torna-se bastante propensa ao idealismo do protagonista, na medida

${ }^{16}$ Cf. STENDHAL, [s.d.], p. 18.

${ }^{17}$ Sucede a Baltasar, no fundo, aquilo que Tolstoi, em Ensaio Sobre o Ciúme (1821), refere aquando do desejo de um homem por uma mulher: «Uma mulher bonita diz coisas absurdas; só que nós, em vez de ouvirmos essas tolices, só conseguimos ouvir os mais sensatos pensamentos. Ela continua a dizer barbaridades, e age de modo hediondo, e mesmo assim persistimos em ver tudo de modo agradável» (ed.ut.: Carcavelos, Coisas de Ler Ediçôes, [s.d.], p. 31). Mais: «Se ela se inibe de dizer disparates e fazer asneiras e, para além disso, ainda é bonita, ficamos absolutamente convencidos de que ela é um paradigma de sabedoria e de moralidade» (id., ibid.). 
em que Mécia, fazendo prova de uma significativa concentração, tem o cuidado de não dizer ou cometer disparates, exibindo, com uma disciplina apreciável, uma contenção que contribuiu para que o morgado, até certo ponto do enredo pelo menos, acentue a ideia de se achar perante uma mulher-anjo.

Repare-se, a propósito, que esta inflação da protagonista (a elevação à condição de mulher-anjo), causada pela percepção idealista de Baltasar, pela "cristalização", tem o seu reverso numa deflação que a rebaixa ao estatuto de mulher vil. Em ambos os casos, as avaliações de Baltasar, determinadas por um elevado grau de exigência, sem meio-termo (feroz exigência, própria do herói romântico, para quem o amor significa um estado absoluto e requer uma entrega irredutível), desajustam-se da realidade da protagonista. Mécia está longe de poder ser considerada na proporção de uma mulheranjo, mas, não obstante a sua personalidade falsa e incoerente, também convém dizê-lo - anda bastante afastada das perversóes de outras mulheres fatais e vis que proliferam na literatura romântica, não sendo comparável a uma Velléda (Chateaubriand), a uma Cécily (Sue) ou a uma Carmen (Mérimée). ${ }^{18}$ Digamos que se trata simplesmente de uma moça, com seu "quê» flagrante de imaturidade, que não alinha pelos códigos sentimentais do Romantismo, apesar de os dominar com fins manipuladores, preferindo o gozo da leviandade amorosa, ao que se lhe acresce a cautela, seguindo os conselhos paternos, de procurar um noivo abastado. Daí a inevitável ruptura com Baltasar, que, como comenta Alexandre Cabral, «é um homem estranho que tem do amor e da fidelidade da mulher umas concepçôes radicais, que o podem conduzir à perversidade e ao crime». ${ }^{19}$

3. Narcotizado, Baltasar apaixona-se por Mécia, convencido de que achou uma mulher-anjo (a sua mulher-anjo), sem tomar em consideração

${ }^{18}$ Sobre estas três mulheres fatais em particular, veja-se o estudo de Mario Praz La carne, la morte e il diavolo nella letteratura romântica, Firenze, Sansoni Editores, 1966; PRAZ, 1977, p. 167.

${ }^{19}$ CABRAL, 1989, p. 585. 
os avisados conselhos do primo. Temos uma evidente mentira contida na simulação de Mécia, no simulacro que enceta da sua personalidade, na teia sentimental que lança a Baltasar e que lhe paralisa o discernimento crítico (fazendo-se passar por aquilo que deveras não é), narcotizando-o.

Daqui sucede que, em boa medida, o desejo que Baltasar nutre, nestas primeiras páginas da narrativa, pela morgada desponta da sua incapacidade de desmentir as atitudes e as palavras e até os silêncios da moça. O fidalgo desconhece a Mécia incoerente e falsa, o seu pendor leviano e interesseiro, as dissimulações que engendra sem escrúpulos. Não perscruta nem questiona o comportamento verbal e não-verbal da moça. Além disso, não dá crédito às advertências pertinentes do primo. Daí que não consiga detectar a mentira, e que esta marque presença fundamental na sua génese amorosa. Quer dizer, Baltasar apaixona-se por uma imagem idealizada da moça, forjada à custa de uma dissimulação da sua identidade real, levada a efeito pela própria, imagem idealizada essa (leia-se igualmente: imagem mentirosa) que encontra no idealismo do rapaz uma base ampla e segura para se ancorar (o ser cede lugar ao parecer, e o parecer torna-se ser). Os desmentidos possíveis dessa imagem, ou se quisermos, dessa mentira - os avisos de D. José e os indícios que apontam para o inverso de uma mulheranjo - não bastam para rebater a mentira, desmascarando-a. Não se afiguram suficientes para detectar o sumiço dessa personalidade autêntica face à fingida. A imagem que transparece revela-se mais forte do que a identidade sumida. Temos então uma linha de fuga à verdade - a mentira decorrente da simulação - que cumpre o objectivo de estimular no moço o desejo, sendo que essa linha de fuga assenta na relação de desejo que Baltasar mantém por Mécia. ${ }^{20}$

${ }^{20}$ Recorra-se à concisão de uma fórmula, para resumir esse relacionamento desiderativo (partimos, alterando-os em conformidade com as nossas necessidades, dos esquemas cognitivo-emocionais de Carlos C. del Pino, Teoría de los sentimientos, Barcelona, Tusquets Editores, 2000; DEL PINO, 2003, p. 4, 48-50), em especial no que toca à mentira que o estrutura (a imagem falsa de Mécia). A fórmula, aparentemente complexa, é, na verdade, muito simples e (daí a sua pertinência) simplificadora: [1] $f(S / i m O b F) C x$. 
Vale a pena prestar atenção ao episódio da estalagem, onde Baltasar, D. José, Lopo e Mécia pernoitam. Todos vão, após o jantar, dormir, todos menos Baltasar que passa a noite acordado, virado para o Tâmega a idealizar, numa vertigem sentimental que mescla amor e absoluto, a filha de Lopo. $\mathrm{O}$ contexto apela ao misticismo. Ouve-se a cândida piedade de S. Gonçalo através da celebração que provém das celas de monges. Este louvor religioso acaba por não funcionar como pano de fundo sobre o qual Baltasar idealiza Mécia, na medida em que o protagonista ergue entre si e a realidade uma trincheira intransponível. A realidade exterior - os louvores a S. Gonçalo, neste caso - nada dizem ao fidalgo, completamente fixado em Mécia. Não custa supor que o que aqui se diz é a conversão da moça num patamar que é o da sua divinização. Na mente de Baltasar, Mécia vale infinitamente mais do que os louvores piedosos que se ouvem do mosteiro. Sublinhemos bem a importância deste imaginário masculino, representado por Baltasar, que converte a mulher numa fonte de

Segundo esta fórmula, atinente ao relacionamento desiderativo do sujeito com o objecto, o chamado functor inicial (modulador da actuação, isto é, tipo de modalizador mobilizado pelo sujeito na construção desiderativa) consiste no sentimento que o objecto $(O)$, neste caso Mécia, provoca no sujeito $(S)$, na sua relação com ele. Esse sentimento, sabemo-lo, é o desejo. Mas se Mécia funciona como um objecto provocador do desejo de Baltasar, como um objecto de desejo, convém acrescentar que estimula esse desejo simulando, quer dizer, desencadeia-o revelando-se em termos de objecto falso $(O F)$. Isto implica que Baltasar capta Mécia não na totalidade daquilo que é, quer dizer, em todas as partes que a constituem e que a constituem autenticamente, mas capta-a tão-só em termos da imagem que a moça procura dar e convencer de si $(\mathrm{imO})$, a imagem inautêntica de uma moça inocente e angélica. Quanto a $(C x)$, representa o inapagável contexto em que Baltasar e Mécia - $(S)$ e $(O)$ - se situam (o ambiente material e simbólico). Esta fórmula resumitiva da relação Baltasar-Mécia - relação sujeito/objecto - chama, portanto, a atenção para o facto de não ser tomada em conta, por parte do sujeito, a situação de o objecto ter forjado a construção de si mesmo, iludindo o sujeito no seu relacionamento desiderativo. 
exaltação superior à que provém de Deus, porque foca a opção de fundo que o Romantismo trouxe, a esse nível, relativamente ao Antigo Regime: a desconfiança de que a única via cabal e indiscutível para atingir a infinitude e o absoluto esteja em Deus. O rol de crenças codificadas pela religião-dogmas e outras verdades de Fé, irrefutáveis - perde a homogeneidade e o consenso que detinha no tradicional mundo de matriz transcendente. O Romantismo abriu linhas de fuga e derivaçôes afectivas que enfatizam o amor horizontal entre dois seres onde antigamente se valorizava o amor vertical que partia do homem para Deus e que se acreditava recíproco.$^{21}$

Portanto, o que Mécia gera no interior de Baltasar é algo que arrasta o jovem para o limiar de outro êxtase que não aquele que as luzinhas das celas supostamente reflectem (ou seja, o enlevo não provém forçosamente de Deus ou da devoção a S. Gonçalo). A tais luzinhas é o fidalgo indiferente. Começa a desenhar-se aqui aquela ruptura insensata com Deus e que consiste em fazer de Mécia uma divindade. Encontramo-nos perante o que René Girard nomearia de transcendência desviada, por oposição à transcendência vertical (a que procede de Deus). Ou, se quisermos, a transferência do absoluto celeste (transcendência vertical) para o ideal amoroso (transcendência assim desviada). Desta transferência se nutrem a utopia prometeica e todas as utopias messiânicas e as ideologias visionárias (incluindo o ateísmo filosófico) que denegam ou escondem o Criador e que intentam colocar o homem no lugar de Deus. Deste modo, o outro passa a ser o deus que negamos em Deus. Torna-se no caminho do absoluto e do universal. E o religioso passa a adquirir um rosto humano, o do nosso vizinho, o do próximo. Daí que Jean-Pierre Dupuy nos diga que «Le religieux se survit à lui-même sous des formes de

${ }^{21}$ Nesta deriva está inscrito o primeiro passo que desembocará, mais tarde com Nietzsche, com a sua ideia de «niilismo», e depois com Marx, para quem a religião não passa «do ópio do povo», na tentativa de matar Deus, negando-o, e de proclamar em seu lugar o homem, divinizando-o (noção em certo sentido recuperada por alguns filósofos da actualidade, em nome do que apelidam de espiritualidade laica, como os franceses Luc Ferry ou André Comte-Sponville). 
plus en plus caricaturales». ${ }^{22}$ Importa acentuar aqui que a moça nunca deterá verdadeiramente esse estatuto divino, em virtude dos sucessivos desencantos com que terá de lidar Baltasar. No entanto, Baltasar nem por isso difere dos muitos outros heróis românticos que viram na mulher, como haveriam de o ver na poesia e na arte em geral, um passaporte de acesso ao absoluto e ao infinito. $\mathrm{O}$ narrador, a dado passo, dá-nos uma percepção da moça (e que não podemos senão imputar à vertigem amorosa que percorre o fidalgo), que não destoaria da que o idealismo sentimental desses outros heróis românticos dariam de suas amadas. Eis a passagem a que nos referimos:

E o sonhador, por noute alta, quedava-se ainda debruçado sobre a guarda da ponte. Ao fazer-se a primeira luz da manhã, lá estava ainda. Rumorejavam-lhe desde as alvoradas dos pássaros umas vozes humanas em toada soturna. Vinham da banda do mosteiro. Avizinhou-se à igreja e escutou. Era a oração matinal dos monges: o salmear triste dos homens lá dentro e cá fora os trilos hímnicos das aves. Consonância, todavia, para transportes daquela alma, que se entranhara toda em Deus, se, naquela hora, a imagem alvíssima de uma mulher adormecida lhe não estivesse dizendo: «Olha como da terra os turíbulos perfumam hosanas ao Senhor que assim me criou! Eu não oro com os servos do bendito das alturas, nem canto com as avezinhas dos arvoredos; dormem meus olhos, mas a minha alma vela; sonho que me vejo entre irmãos, vestidos de resplendores, clamando com eles: Glória ao criador do céu e da terra, dos mares e das estrelas, dos silêncios da noute alta e dos salmos festivais da aurora. $»^{23}$

De novo, reaparece o mosteiro e o seus monges a cruzarem-se com o êxtase amoroso de Baltasar; e, de novo, a mesma situação espacial: o fidalgo continua imóvel na ponte, lá permaneceu a noite, e, diante dele, o mosteiro. No início da noite, eram as luzes das celas que denunciavam a

${ }^{22}$ DUMOUCHEL; DUPUIS, 1978, p. 64. O mesmo é dizer, desta vez com palavras do próprio Girard, que «La transcendance déviée est une caricature de la transcendance verticale» (GIRARD, 2000, p. 78).

${ }^{23}$ CASTELO BRANCO, 1972, p. 51-2. 
presença dos monges e que supunham a devoção a S. Gonçalo, agora, «Ao fazer-se a primeira luz da manhã», são vozes «em toada soturna» que irrompem do claustro. Avizinhando-se da igreja, Baltasar percebe que se trata da oração matinal dos monges. O mosteiro e as vozes que de lá se ouvem são tintados de conotações disfóricas, opondo-se à atmosfera algo idílica que rodeia o mancebo apaixonado: para além de nos consignar que são "vozes humanas em toada soturna», o narrador, num categórico contraste com o som das aves, descreve essa oração matinal como sendo «um salmear triste dos homens». Enquanto isso, no exterior das paredes do mosteiro, temos que estas primeiras horas da manhã se conciliam à perfeição com o idealismo amoroso que acomete a personagem. O enlevo sentimental de Baltasar parece ter voz no mundo aprazível e harmonioso das «alvoradas dos pássaros» e dos "trilos hímnicos das aves». O mesmo é dizer que o despertar do canto das aves, destilado que é do tópico da ideia de felicidade, sugestivamente enuncia e representa em registo melodioso essa tremenda viragem na vida sentimental do herói que é o seu despertar para o amor. $\mathrm{E}$ a comprovar que se trata deveras de uma viragem, note-se a afinidade de Baltasar com as gentes do mosteiro. Tendo a alma «entranhada toda em Deus», as vozes que emanam do convento soar-lhe-iam, presume-se daquilo que nos revela o narrador, a um apelo a que não saberia resistir. Aliás, a forte ligação de Baltasar a Deus, se não quisermos falar no resumo que dá de si a Lopo de Sampaio (e que lhe valeu a alcunha de Nemrod transmontano), e que indicia uma inamovível tendência de eremita que, no final da narrativa, reaparecerá, como se disse, a consubstanciar a santificação da personagem, essa forte ligação ao Criador está exposta na sua fraterna amizade por Frei António de Cristo. ${ }^{24}$

Todavia, a paixão vem alterar por completo a inclinação religiosa do mancebo. Não lhe quebra a crença em Deus, essa decerto inabalável

${ }^{24}$ Como trecho que denota a presença desse lado religioso de Baltasar, a que não falta a inclinação do fidalgo para o recolhimento e a vida solitária nem tão-pouco a comparência (rememorada) do devotado amigo Frei António de Cristo, cite-se a passagem em que, dominado por "tenebrosas cogitações», o rapaz, qual Tristão sem Isolda, erra desvairado pela floresta, até encontrar 
conforme demonstrará o retorno à fé na parte final da intriga, porém, o que não tende a ser coisa pouca para uma alma até então sublimada em Deus, desloca-lhe, digamos assim, a propensão religiosa. $\mathrm{O}$ fidalgo não se rende às orações que ouve, vindas do mosteiro, porque a monopolizar-lhe a atenção, e revestida de um contexto que a torna participante da santidade, está a indelével presença de Mécia. Tudo o resto, pássaros e monges, como que parece dissipar-se. A imagem da morgada alvíssima, falando-lhe, não solicita uma suposição de realidade da parte do leitor. Sabemos que, nesse instante, Baltasar não pode estar senão sonhando acordado, o que fica tácito não apenas pelo teor irreal do conteúdo das palavras atribuídas a Mécia como pela insistência no facto de que a voz que fala, a da moça, provém de um corpo adormecido; e deduz-se, sem dificuldade, que as palavras que o protagonista ouve do corpo adormecido que assim fala provenham da sua imaginação incendiada de paixão e de misticismo. O compromisso da

inusitadamente a cabana de Francisco de Jesus. $\mathrm{O}$ momento não deixa de ser indicativo do trajecto final da personagem, ou, pelo menos, de que o recolhimento e a fé apaziguam a obstinada violência do ciúme e da rivalidade, não pondo de lado que venham, como efectivamente acontecerá, a salvar a personagem do abismo amoroso. Eis a referida passagem: «Ao pé da cabana de Francisco de Jesus fora dar consigo o errante Baltasar. Perto desta cabana esboroada bracejavam as ramarias de um carvalho agigantado. Num dos esgalhos que rompiam do tronco, à altura de homem, estavam entalhadas umas letras quase sumidas, que diziam Jesus. Baltasar quedou largo espaço contemplativo na choça arrasada e na inscrição. Os pensamentos excruciantes deram-lhe tréguas; e logo as lágrimas lhe assomaram aos olhos como embelezados na sublime tristeza que se assentava na padieira bruta daquele casebre. Depois, entrou no pequeno recinto, delimitado pelas paredes derruídas, e não achou vestígio da vida que ali passara. Sentou-se na pedra, que devia ter sido o escabelo do morador daquele gruta, e recordou-se da suave tranquilidade de sua vida no Alvão, nas serranias de Barroso e na soledade sepulcral do seu solar das Olarias. Avoejou-lhe de salto ao coração a imagem de Frei António de Cristo, que lhe dizia: "Vem contar-me os teus dissabores, que eu é que sei o azedume dessas lágrimas»». (CASTELO BRANCO, 1972, p. 142). 
passagem tende a ser outro: o de nos fazer assistir ao estatuto de santidade que a rapariga ganha aos olhos do morgado. E o transplante, vamos assim dizer, da moça para a esfera da santidade (não nos atrevemos a dizer para a esfera da deificação) consiste na sua deslocação para um local espiritual e imaterial que diríamos ser o Paraíso. Mécia, ao que afiança, sonha-se projectada nessa morada de santos tanto mais divina quanto manifestamente afastada da realidade empírica dos que oram nos mosteiros e do canto das aves dos arvoredos. E, nesse indeterminado e imaterial espaço que se aparenta ao Éden, a filha de Lopo de Sampaio, em uníssono com «irmãos, vestidos de resplendores", clama uma oração laudatória a Deus. Este sonho que Mécia, dormindo, confessa ao sonhar acordado de Baltasar, como se o transe de uma comunicação telepática ou uma espécie de hiperestesia indirecta do pensamento os ligasse, põe em imagem uma beatificação da personagem - o que tanto é como defini-la pelo angélico preceito da virtude e da inocência -, mas põe sobretudo em imagem o idealismo amoroso do fidalgo e leva a concluir pelo reforço da sua compleição sentimental.

4. Adoptando agora a perspectiva de Mécia, retenha-se que esta seduz Baltasar, com a plácida cumplicidade do pai, não imaginando que, por detrás do morgado educado e sensível, se esconde a presença de uma mente possessiva e ciumenta. De facto, essa índole desfavorável não se encontra à vista nestes capítulos iniciais da intriga. Nenhum leitor suspeita do temperamento que se alberga por detrás da cortesia de Baltasar, não havendo quaisquer sinais consistentes no sentido de indicar ou de indiciar que o herói sofre de uma compleição possessiva e irascível, pior, que resvalará para o crime. Não existem, por agora, interstícios de contacto que permitam a Mécia desconfiar do temperamento intempestivo do morgado de Olarias. Nada há que a encaminhe para a previsão do desafortunado trajecto que está para vir; a filha de Lopo Sampaio não desconfia do inexorável destino a que se entregará Baltasar. Da mesma maneira, o leitor, a menos que possua uma insólita clarividência, não está em condições de depreender que está para vir a fulgurância de um trajecto mortífero. A irrepreensível índole sensível e delicada que, nesta parte da intriga, Baltasar ostenta como que o situa o mais longe possível desse porvir fatídico que lhe é destinado. O mesmo será 
afirmar que a virtude social de Baltasar, presente no fino trato cortês que o destaca da incivilidade do primo, deixa supor uma virtude íntima avessa a qualquer tipo de desmesura. Se soubéssemos que D. José viria a cometer o desastre dalgum crime ou até mesmo que simplesmente se envolvesse nalguma violência circunstancial, decerto que a notícia não traria grande estupefacção. Corroboraria, até certo ponto, a rudeza e o descomedimento do senhor da casa de Alijó. Tratando-se de Baltasar, instala-se obrigatoriamente a perplexidade de saber como é que foi possível a polidez transmudar-se em violência, ou dizendo mais correctamente, a perplexidade de saber como é que a polidez, em vez de enunciar exclusivamente uma personalidade virtuosa, afinal também encobre uma personalidade problemática (possessiva e criminosa). ${ }^{25}$

${ }^{25}$ Refira-se, a propósito, que a perplexidade perante tal mudança não será tanta se tivermos em conta aquilo que nos diz André Comte-Sponville acerca da polidez (André Comte-Sponville, Petit Traité des Grandes Vertus, Paris, Presses Universitaires de France, 1995; ed. ut.: Pequeno Tratado das Grandes Virtudes, 1995, p. 17-24). Entre outras reflexões, o também autor de Traité du Désespoir et de la Béatitude nota que a noção de polidez consiste num artifício, ou melhor, para não fugir ao vocabulário que Comte-Sponville usa, de uma "qualidade formal», através da qual se consegue obter uma aparência de moral. Como escreve: «A polidez [...] é uma aparência de moral: agir polidamente é agir como se fôssemos virtuosos». Por essa razão, a polidez não deve ser lida como um sinónimo de virtude, porquanto aparenta virtude. Daqui se explica que, por detrás de pessoas extremamente polidas, se possam refugiar personalidades ignóbeis e crapulosas (o caso de alguns nazis muito polidos). Nesse sentido, a polidez funciona como uma película dissimuladora do verdadeiro carácter da pessoa, simulando-lhe virtude. Ou seja: trata-se de um simulacro que imita a virtude. É por isso que ficamos nestas primeiras páginas da narrativa com uma impressão favorável de Baltasar e sem a menor suspeita do temperamento problemático que se camufla por detrás da sua polidez. Por isso também que D. José - grosso, tosco, rude e inculto - nos suscite imediata relutância, apesar de essa notória e característica falta de polidez lhe atestar uma autenticidade, a autenticidade que o primo, justamente por ser polido, não demonstra possuir. 
Existe assim uma parte da personalidade do protagonista, incongruente com a que nos é dada a conhecer nestas primeiras páginas do enredo, que se mantém, a bem da harmonia entre os intervenientes e em benefício da inclinação de Baltasar por Mécia, ocultada. Esta incongruência dissimulada, ${ }^{26}$ quando for retirado o véu que a cobre, funcionará no sentido de quebrar a ligação sentimental entre os dois jovens, tal como sucederá com a descoberta gradual, posto que rápida, da simulação. Será factor de dissensão e de conflito (da mesma maneira que agora a sua dissimulação contribui para uma harmonia entre as duas personagens), dando a conhecer uma face rasurada da verdade, ainda que nefasta. É por essa razão que a sua dissimulação nestes primeiros capítulos do enredo se pode considerar também, se bem que num sentido eventualmente mais moderado do que o da mentira, como uma linha de fuga à verdade, em virtude de esta não ter sido inteiramente revelada.

Se Mécia soubesse de antemão que Baltasar afinal, para além de extremamente cortês no trato e de revelar uma notória sensibilidade, afinal, dizíamos, também é propenso a comportamentos intempestivos, para não falar nos homicídios que perpetrará, se Mécia soubesse disso, apostaria ainda em cativá-lo, em estimular-lhe o desejo amoroso? Por conseguinte, também Mécia, ao fim e ao resto, acaba por sucumbir a uma imagem idealizada de Baltasar. Seduz o moço baseada na única faceta a que tem acesso da personalidade dele, a faceta mais favorável. Isto indica que Baltasar também acaba, no fim de contas, por desempenhar um certo papel activo na assunção do seu próprio desejo por Mécia. Fornece de si uma imagem que impele Mécia a seduzi-lo, quer dizer, sem a qual provavelmente não haveria processo de sedução. Dito de outro modo: a sedução da moça, o desejo que ela estimula em Baltasar, apenas se verifica porque Mécia somente acede a

${ }^{26}$ Podíamos, a propósito de incongruências dissimuladas, igualmente aludir à de $\mathrm{D}$. José, quer dizer, à falta de coragem e de franqueza que mais tarde revelará aquando do seu noivado com Mécia, quando se vê constrangido a confrontar-se com o primo. Por enquanto, nada leva a suspeitar que o fidalgo alguma vez possa pecar por falta de temeridade ou por falta de sinceridade. 
uma parte favorável da psicologia do morgado. Embora pertença à moça o papel activo de seduzir o rapaz, de lhe despertar uma força desiderativa, não é menos verdade que ela somente cumpre essa função porque desconhece a compulsão ciumenta e violenta da psicologia do seu destinatário. Cumpre-a na medida em que só acede ao lado galante do moço. Muito diferente seria se o morgado de Olarias mostrasse, porventura, a sua outra faceta. Terminaria, por certo, de imediato a estimulação desiderativa. Repare-se que com D. José, cuja personalidade repudia, Mécia, nesta parte da narrativa, não efectua nenhuma tentativa de sedução.

Tudo isto não significa que a moça sofra um engano, que esteja a ser alvo de uma manipulação, de uma mentira. Com efeito - repare-se nesta diferença substancial entre os dois protagonistas -, Baltasar não dissimula essa sua outra identidade (que entrará em cena apoiada nos ciúmes), incongruente com esta primeira, mentindo. Ao inverso de Mécia que simula aquilo que não é (uma mulher-anjo) e que, com isso, dissimula aquilo que é (uma moça leviana e interesseira), o filho mais velho da casa de Olarias não manipula a moça, não lhe mente. A compenetração sensível do mancebo e a sua compostura impecável coexiste com a incongruência de possuir em simultâneo uma índole ciumenta e violenta, embora esta segunda compleição só aflore a partir do instante em que surgem rivais. Mécia só lida com uma parte da personalidade do morgado, a mais favorável, em virtude de Baltasar, por intermédio de um processo interior de selecção comportamental, actuar de modo cortês e delicado e não de maneira possessiva e violenta. As duas actuações integram a personalidade da personagem, mas uma foi aqui activada em detrimento da outra, que ficou assim dissimulada. Acresce que a actuação convocada se adequa à imagem que Mécia transmite. Tomando-a por uma moça angélica e inocente, pela qual sente uma forte atracção, imagem que a protagonista incita, Baltasar ostenta uma forma de ser concertada com essa imagem; adequa-se-lhe com um comportamento impecável, sendo esse comportamento impecável a resposta ajustada que a imagem simulada de Mécia requer. Esta conformação à interlocutora que o cativa visa garantir que esta não lhe desmereça a atenção que lhe presta. Em todo o caso, a ocultação da parte menos favorável da 
personalidade não ocorre pelo viés da simulação (da mentira). ${ }^{27}$ Recordese, a propósito, este trecho, que obedece ao mesmo princípio da adequação comportamental em função dos interlocutores:

- Estou consigo, primo Baltasar - disse o velho -; porém as excepções hão-de ser tão poucas em número, que não possam escurecer os vilaníssimos feitos de homens que se quiseram afidalgar e sair de sua escória pelas portas por onde costumam sair homens de claro sangue e muitos avós nobilitados na história... - É verdade... condescendeu Baltasar Pereira, receando anojar a teimosia do velho, que era pai daquela encantadora menina. - Quem sabe - diria de si consigo o moço - se ela se molesta de que eu lhe vá contradizendo o pai! - É verdade... - repetiu o moço. (o itálico é nosso). ${ }^{28}$

Por conseguinte, a linha de fuga à verdade consigna-se no facto de o herói, a vítima do desejo, apenas dar a conhecer uma parte do seu carácter, a mais favorável, o que tem como consequência enganar Mécia, no sentido em que a encaminha a cometer metonimicamente um erro de interpretação (erro de interpretação por falácia metonímica, diria Carlos del Pino $^{29}$ ): tomar a parte (um dos eus) pelo todo (o sujeito). A fuga à verdade está nessa ilusão de tipo metonímico; ou, se nos quisermos situar a partir do ângulo

${ }^{27}$ Em termos de formulação, eis, no que toca a Baltasar, como podemos resumir esta segunda situação, tendo em atenção que $(Y)$ se reporta ao $e u$ convocado pelo sujeito, em detrimento dos outros múltiplos que constituem a identidade plurívoca de todo e qualquer sujeito: [2] [S(Y/imObF)] Cx. Quanto a Mécia, uma vez que estimula uma relação desiderativa baseada numa parte, ainda que não simulada (verdadeira, portanto), da personalidade de Baltasar, num eu dos vários que Baltasar enquanto sujeito comporta e que o definem (cada sujeito $=\mathrm{eu}+\mathrm{eu}+\mathrm{eu}+\ldots)$, a sua relação com o herói, nesta fase da narrativa, pode ser descrita desta maneira, sendo que $\left(Y_{s}\right)$ se refere ao eu simulado da moça, ( $p$ ) significa uma parte e, consequentemente, (imObp), a imagem de uma parte do objecto: [3] [S(Ys/imObp)] $C x$.

${ }^{28}$ CASTELO BRANCO, 1972, p. 19.

${ }^{29}$ DEL PINO, 2003, p. 49. 
de Baltasar, está na dissimulação, pelo viés da ocultação, que a personagem faz daquela parte menos prezável do seu ser, a qual, se confrontada com a que evidencia nesta fase do enredo, soa incongruente (em suma, na dissimulação da incongruência). É claro que tudo isto supõe psicologias acabadas e estáveis, posto que certas partes delas se possam desconhecer; e se fôssemos partes sem grande todo ordenador orgânico? E se o Baltasar possessivo só existisse - como deixará supor a leitura girardiana que se pode fazer da obra - depois de contactar com a natureza menos apelativa de Mécia, i.e., com a sua faceta reprovável? E podemos ir até mais longe na indagação: em termos luhmannianos, mas sempre no mesmo registo da desmoralização, que tal se a transformação de metonímias em todos metafóricos ('rapaz educado', mulher-anjo, coração, estômago, etc.) for um moderno índice de uma protecção frágil contra a contingência? A nossa heroína, ou todas as suas partes, e o nosso herói, ou todas as suas partes, são desconhecidos obrigados a comunicar. No Romantismo, acontece muito que a comunicação redunde em desastres, não necessariamente trágicos como aqui, enquanto a ordem antiga asseguraria por si só, sem precisar de «o dizer», que herói e heroína não são desconhecidos deste tipo; todavia, a mesma ordem antiga nesta situação (algo anacronicamente moderna, pois isto ter-se-ia passado em Setecentos) não consegue opor uma defesa firme contra estes perigos, apesar de que, pela boca do patriarca amável, declare a heroína e o herói conhecidos, i.e., "primos».

5. O desejo de Baltasar por Mécia baseia-se, como vimos, numa imagem idealizada da moça ou, dito de outro modo, numa imagem falsa ou ilusória da filha de Lopo. Não parece proceder, digamos assim, de uma iluminação súbita - de um coup de foudre. O jovem fidalgo de Olarias depara com uma donzela que julga ser angélica e deseja-a. Isto pressupóe, em conformidade com a sua identidade romântica (é melancólico, sofre «exultações de sua alma», ${ }^{30}$ aprecia a solidão e refugia-se nas serras, etc.), que interiorizou uma imagem-modelo da mulher ideal (a imagem da mulher-anjo).

${ }^{30}$ CASTELO BRANCO, 1972, p. 49. 
Tendo em conta a teoria mimética do desejo de Girard, o desejo de Baltasar pela filha de Lopo leva a pressupor mais: que Baltasar tenha interiorizado o desejo por uma mulher-anjo a partir de algures, vale dizer, a partir de uma mediação externa. $\mathrm{O}$ texto não refere a presença de nenhum mediador externo, mas deixa em aberto a possibilidade de inferirmos que o idealismo, que a personagem projecta na filha de Lopo, provenha de uma mediação externa, eventualmente de uma mediação literária. Esta hipótese interpretativa não é pacífica, na medida em que colide com o desprezo que Baltasar vota aos livros. Porém, a sua propensão para a melancolia, a sua índole taciturna e meditativa, a sua errância solitária pelas serras, afastado da vida social e mundana, a noite que passa acordado, frente ao rio Tâmega, a idealizar Mécia, a lágrima fácil, etc., são tudo atitudes que não soam nada espontâneas. Espontânea parece ser a franqueza de D. José e a sua indomável brutalidade. O comportamento de Baltasar supóe uma tradição sentimental, não sendo de excluir um mimetismo literário (é de resto, convém lembrálo, um ser de papel, o qual supōe papéis; e a caracterização sumária anterior cabe tanto nalgum petrarquismo como nalgum Rousseau). Aliás, nada no texto contradiz o raciocínio probabilístico de que o herói, nos tempos em que se dedicava ao estudo, tivesse sido contaminado pela literatura sentimental. Se agora repudia os livros, nada obsta a que os pudesse ter apreciado no passado, da mesma maneira que largou os estudos que tinha ido começar por iniciativa própria, a despeito da vontade do pai. De resto, diz-lhe a certo momento D. José, querendo fazer valer superioridade em relação ao primo diante de Lopo: «Eu sei cozinhar e tourear. E tu que sabes lá da tua livralhada, meu valdevinos?» (o itálico é nosso). ${ }^{31}$

No tocante a Mécia, pode-se levantar a questão de saber onde é que a moça aprendeu a simular a postura de mulher-anjo e a suscitar o desejo, visto que nem sequer saberá ler e que o comportamento que simula com habilidade pressupóe uma preparação psicológica. A explicação do narrador é um tanto desconcertante. Tendo presente as novelas de Frei Lucas de Santa Catarina, de Gerardo de Escobar e de Peres de Montalvão, novelas cuja

${ }^{31}$ CASTELO BRANCO, 1972, p. 40. 
leitura aconselha e onde se acham «dissimuladas» e «refinadíssimas hipócritas» «donzelinhas», ${ }^{32}$ escreve:

As nossas tresávos liam romances [as novelas acima mencionadas] que explicam bastantemente as virtudes delas.

D. Mécia não lia romances, mas estava impregnada, para assim dizer, da poesia do tempo. Tinha a intuição das galhardas cavalerias, porque o ar de Trás-os-Montes, a educação e costumeiras, aspirações e sentir eram ainda os da Idade Média. ${ }^{33}$

Não sendo indubitável que o sentimento de Baltasar por Mécia tenha origem num desejo despoletado por uma mediação, existe a alternativa, seguindo Philippe van den Bosch, de afirmarmos que o herói ama Mécia, não porque, por exemplo, reencontra na morgada aquilo que encontrou em livros, mas dado que nela ama um ideal: o ideal da mulher-anjo. Citemos as palavras de Bosch:

[...] engano-me se julgo amar um ser. De facto, o que eu amo, ou o que admiro, é a mulher ou o homem ideal, o herói ideal, e só amo seres reais na medida em que eles parecem encarnar pouco mais ou menos esse ideal, dar-lhe carne e vida. Amo também a coragem, a nobreza, a pureza, a doçura, a bondade, a justiça, que são todas elas virtudes ideais das quais os seres participam em maior ou menor grau, e amo os seres tanto mais quanto mais as possuírem. Mas vejo claramente que o verdadeiro objecto do meu amor é o ideal. ${ }^{34}$

Mas seja porque deseja Mécia devido ao contágio de uma mediação externa, ou seja porque nela ame o ideal da mulher-anjo, o certo é que - e aqui pode entrar como explicação muito possível a teoria do desejo mimético formulada por Girard -, ao aperceber-se de que, afinal, Mécia não é quem aparentava ser, Baltasar não colocará um ponto final na relação

32 Cf. CASTELO BRANCO, 1972, p. 140-141.

33 CASTELO BRANCO, 1972, p. 141.

${ }^{34} \mathrm{BOSCH}, 2001$, p. 158. 
e entregar-se-á à paixão funesta. Daqui provirá, como sabemos, o trajecto amoral e associal do protagonista antes de se fazer, pelo viés de uma expiação reparadora, eremita e santo.

\section{Referências bibliográficas}

BOSCH, Phillipe van den. La Philosophie et le Bonheur. Paris: Flammarion, 1997; ed. ut.: A Filosofia e a Felicidade. Trad. Madalena Poole da Costa. Lisboa: Instituto Piaget, 2001.

CABRAL, Alexandre. Dicionário de Camilo Castelo Branco. Lisboa: Caminho, 1989.

CASTElO BRANCO, Camilo. O Santo da Montanha. Porto: Typographia do Commercio, 1866. ed.ut.: 6. ed., conforme a 1. a, última revista pelo autor, Fixação do texto por Laura Arminda Bandeira Ferreira, Nota preliminar por Maria Aparecida Santilli, Lisboa, Parceria A.M. Pereira, 1972, p. 186. Doravante usaremos a sigla $S M$. para nos referirmos a esta edição.

DEL PINO, Carlos C. Teoria dos Sentimentos, Trad. de Miguel Serras Pereira, Lisboa, Fim de Século, 2003, p. 4, 48-50),

DUMONT, Louis. Essais sur l'individualisme. Une perspective anthropologique sur l'idéologie moderne. Paris: Éditions du Seuil, 1983.

DUMOUCHEL, Paul; DUPUIS, Jean-Pierre. L'enfer des choses. René Girard et la logique de l'économie. Posface de René Girard. Paris: Éditions du Seuil, 1978.

GIRARD, René. Mensonge romantique et vérité romanesque. Paris: Éditions Bernard Grasset, 1961; ed.ut.: Paris: Hachette, 2000.

LACAN, Jacques. Joyce le Symptome, in L'Ane, n. 6, Outomne 82; ed.ut.: Joyce o Sintoma, trad. de Miguel Carmona da Mota, supervisão da trad. de José Martinho, um prefácio de José Martinho («Todos Pos-Joycianos») e outro de Eric Laurant («Gozo o Sintoma: singularidade duma estrutura subjectiva»), Coimbra: Escher, 1986.

LUHMANN, Niklas. Soziale Systeme. Grundisse einer Allgemeine Theorie. Frankfurt am Main: Suhrkamp Verlag, 1984; ed.ut.: Sistemas sociales. Lineamentos para una teoría general, Trad. de Silvia Pappe y Brunhilde Erker, 
bajo la coordinación de Javier Torres Nafarrate, 2. ${ }^{a}$ ed. [1. ${ }^{a}$ ed.: (1991)], Barcelona/Santafé de Bogotá/México, Anthropos/Universidad Iberoamericana/CEJA, Pontificia Universidad Javeriana, 1998.

PEQUENO Tratado das Grandes Virtudes. Trad. Maria Bragança. Lisboa: Editorial Presença, 1995.

PRAZ, Mario. La chair, la mort et le diable dans la littérature du XIX siècle. Le romantisme noir. Trad. par Constance Thompson Pasquali. Paris: Éditions Denöel, 1977.

SOUSA, Sérgio Guimarães. Personagens camilianas sob o signo de Rousseau. Agália: Revista de Ciências Sociais e Humanidades, n. 93/94, p. 135-52, 1. ${ }^{\circ}$ semestre de 2008.

SOUSA, Sérgio Guimarães. Entre-Dois. Desejo e Antigo Regime na Ficção Camaliana. Braga: Instituto de Letras e Ciências Humanas da Universidade do Minho, 2005.

SOUSA, Sérgio Guimarães. Rivalidade e Desejo n'O Santo da Montanha. O Marrare. Periódico do Setor de Literatura Portuguesa, Rio de Janeiro, Instituto de Letras/UERJ, ano 5, n. 6, p. 101-11, nov. 2005. 


\section{Resumo}

Em 1866, Camilo Castelo Branco publica O Santo da Montanha. Trata-se de uma narrativa que põe em cena uma paixão devastadora entre dois protagonistas incompatíveis. $\mathrm{O}$ trajecto trágico de Mécia e Baltazar pode explicar-se sem custo com base na teoria mimética do desejo (R. Girard). No entanto, é preciso, desde logo, questionar a origem do desejo. Ou seja, reflectir sobre a razão pela qual duas personagens nutriram desejo uma pela outra, apesar de tudo nelas revelar diferenças intransponíveis.

\section{Abstract}

In 1866, Camilo Castelo Branco publishes O Santo da Montanha. In this novel the destructive passion of the incompatible protagonists is portrayed. The tragic outcome of Mecia and Baltazar can easily be explained by resorting to the mimetic theory of desire (R. Girard). But first of all, we must first begin by questioning the origin of desire. That is, we must reflect upon the reason why two characters nourished the desire for each other when their differences seemed at all lights indissoluble. 